\title{
THE NATIONAL PARKS AND RESERVES OF ARGENTINA
}

\author{
By G. Dennler de La Toun, M.D., D.Sc.
}

The idea of national parks in Argentina started in 1903 with the gift of 7,500 hectares to the Argentine nation by Francisco P. MIoreno, one of the earliest Argentine naturalists. But even this area, since greatly enlarged, did not receive legislative guarantee until 1934, after the late Dr. Hugo Salomon had repeatedly insisted that the integrity of national parks and reserves could only be assured by legal enactment. Fourteen areas, including three still only projected, are set aside as national parks or other forms of nature reserves in Argentina. Of the six northerly reserves all but Iguazú and Finca El Rey belong to the Chaco formation. All the southern reserves lie in the Cordillera of the Andes, except for Laguna Blanca in the Precordillera and the national monument Los Bosques Petrificados in the Patagonian plateau. Los Alerces, Nahuel Huapi, Lanin and Iguazu conform more or less to the requirements of national parks laid down by the Convention on Nature Protection and Wild Life Preservation in the Western Hemisphere 1940 ; this the Argentine Government has signed.

All national parks and reserves except Los Copahues are controlled by the Bureau of National Parks. The first consideration of the Bureau has always been tourists and this has sometimes conflicted with nature conservation. The policy of attracting tourists reached its zenith during the Peron regime, when a roulette table was set up in Nahuel Huapi and there was propaganda for deer hunting as a "new attraction" in the Lanin and Nahuel national parks. Such artificial attractions are quite unnecessary, for most Argentine national parks offer an abundance of natural beauties and superb landscape panoramas.

There are two ways of reconciling tourism and nature conservation. One is to establish strict wild life reserves apart from national parks, the other to form inviolable sanctuaries within the parks themselves. For many years the author has been recommending both these measures.

Among the animals most in need of protection in Argentina are the Andean deer " huemul", Iippocamelus bisulcus, and the dwarf deer "pudu ", Pudua pudu. These are threatened not only by "development" and poaching, but by the introduction of the European red and fallow deer in park areas. 
Tiue Andean Parks and Patagonian Resenves and Monuments

Nairuel Huapi National Park. 785,000 hectares $(\mathbf{3 , 0 0 0}$ square miles). Started in 1903 through the gift of 7,500 hectares by F. P. Moreno. Confirmed at its present size in 1934, but almost one-third is private property devoted to farming. Only 60,000 hectares (260 square miles) is strict nature reserve.

Purpose.-To preserve the natural beauties of the lakes, forests and high snow-covered peaks.

Fauna.-The huemul and the pudu have been almost eradicated by poaching, by the dogs of sheep-breeders and by the introduction of European deer. The fish-otter " huillin", Lutra provocax, the Patagonian armadillo "piche", Zaëdyus pichiy, and the chinchilla-like vizcacha de la sierra, Lagidium boxi, once plentiful are now scarce. Even the guanaco, Lama guanicoe, has decreased.

The condor, Vultur gryphus, is the most important bird; others are the black and white eagle, Geranoaëtus melanoleucus australis, and the elegant " peuquito", Accipiter chilensis. The forest borders are enlivened by the red-throated chucao, Scelorchilus rubecula, the tyrannide "fio-fio", Elaenia albiceps chilensis, and the Patagonian zorzal, Turdus falcklandi magellanicus. A colony of the black-headed cormorant, Phalacrocorax atriceps, occupies rocks on Victoria island in Nahuel Huapi lake.

Flora.-The typical forest of the mountainous region consists of an association of an austral beech, Nothofagus dombeyi, and a kind of bamboo, Chusquea culeou, the "colihue " originator of many forest fires. Other trees seen everywhere are the lenga and the ñire, Nothofagus pumilio, and $N$. antarctica. The Chilean cypress, Libocedrus chilensis, is found in small groups associated with bushes such as the heath-like Fabiana imbricata; a kind of broom, Lippia juncea, and other Verbenaceac and Rhamnaceac. Very beautiful are the thickets of arrayan, Myrceugenia apiculata, an Andean myrtle with ebony-coloured wood, whose dark green foliage contrasts wonderfully with its snow-white shining flowers.

LANin National Park. Established 1937. 395,000 ha. (1,500 sq. miles).

Purpose.-Preservation of mountain landscape and conservation of araucaria forest (Chile pine). Dotted with lakes and thick forest, it is dominated by the inactive Lanin volcano. 


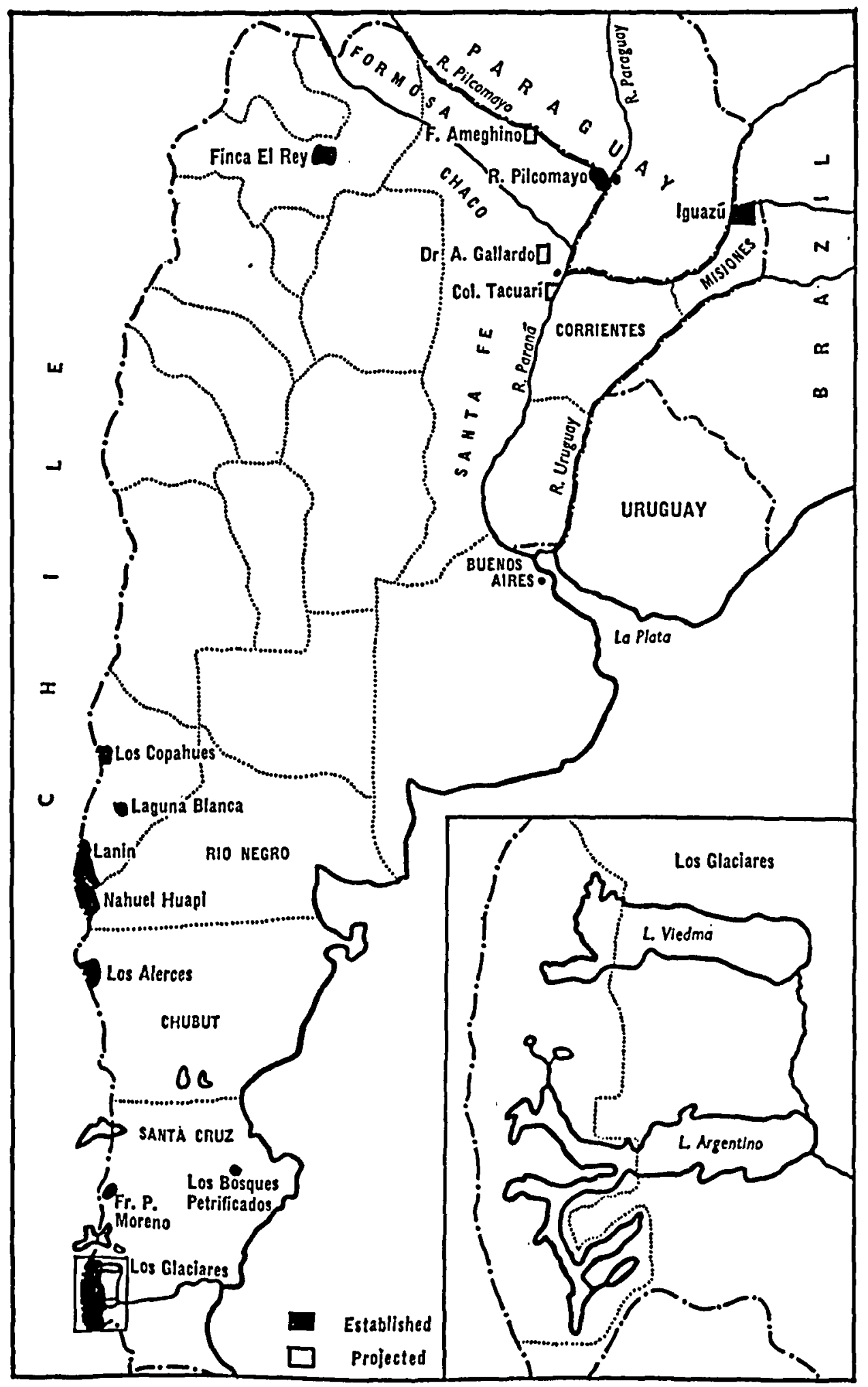


Fauna.-The park adjoins Nahuel Huapi and has the same fauna.

Flora.-Besides the beautiful forests of araucaria partly mixed with coihué, the austral beech, Nothofagus dombeyi, there are the pellin, $N$. obliqua, the lenga, $N$. pumilio, and the rauli, $N$. procera. Also preserved are the dwarf cypress, Dacrydium foncki, two Andean cypresses, Libocedrus chilensis, and Pilgerodendron uviferum, and the mañiu, Podocarpus andina.

Los Alences National Park. Established 1937. 263,000 ha. (1,000 sq. miles).

Purpose.-Preservation of immense forests of alerces, Fitzroya cupressoides (= patagonica) and woods of maitén, Maytenus boaria, and of the beautiful glacial lakes.

Fauna.-Besides armadillos and the fish-otter, the mole rat, Chelemys v. vestitus, is found here, and, among birds, the Patagonian hawk, Accipiter chilensis, the white-throated falcon, Phalcoboenus albogularis, and the barcino duck, Nettion flavirostre.

Flora.-Besides alerces and maitén, the lenga and the ñire, are characteristic.

Los Glacianes National Park. Established 1937. 670,000 ha. (2,600 sq. miles). Sec map inset.

Purpose.-Preservation of typical fauna and flora of the extreme south of the Cordillera of the Andes. This is the most beautiful but least known of the national parks. The glaciers between the FitzRoy and Paine peaks run down to the immense lakes Argentino and Viedma, sometimes dropping huge blocks of ice into them with a thunderous roar.

Fauna.-The huemul and pudu are present, though reduced in numbers. The southern puma, Puma concolor pearsoni, and Magellan's fox, "culpeo," Pseudalopex culpaeus magellanica, are preserved here, without danger to cattle and sheep breeding. The guanaco, the mountain vizchacha, Lagidium wolffsohni, the mole-like silky tuco-tuco, Ctenomys sericeus, and the rabbit-rat, Rheithrodon cuniculoides hatcheri, all rare animals, are present. Among the birds are Darwin's rhea, Pterocnemia $p$. pennata, the flying steamer duck, Tachyeres patachonicus, the condor and the black and white eagle.

Flora.-The principal trees are lenga, nire, the southern coihué, the hard-wood Maytenus magellanicus, and the small maiten, $M$. disticha. Typical shrubs are the berberis, including 


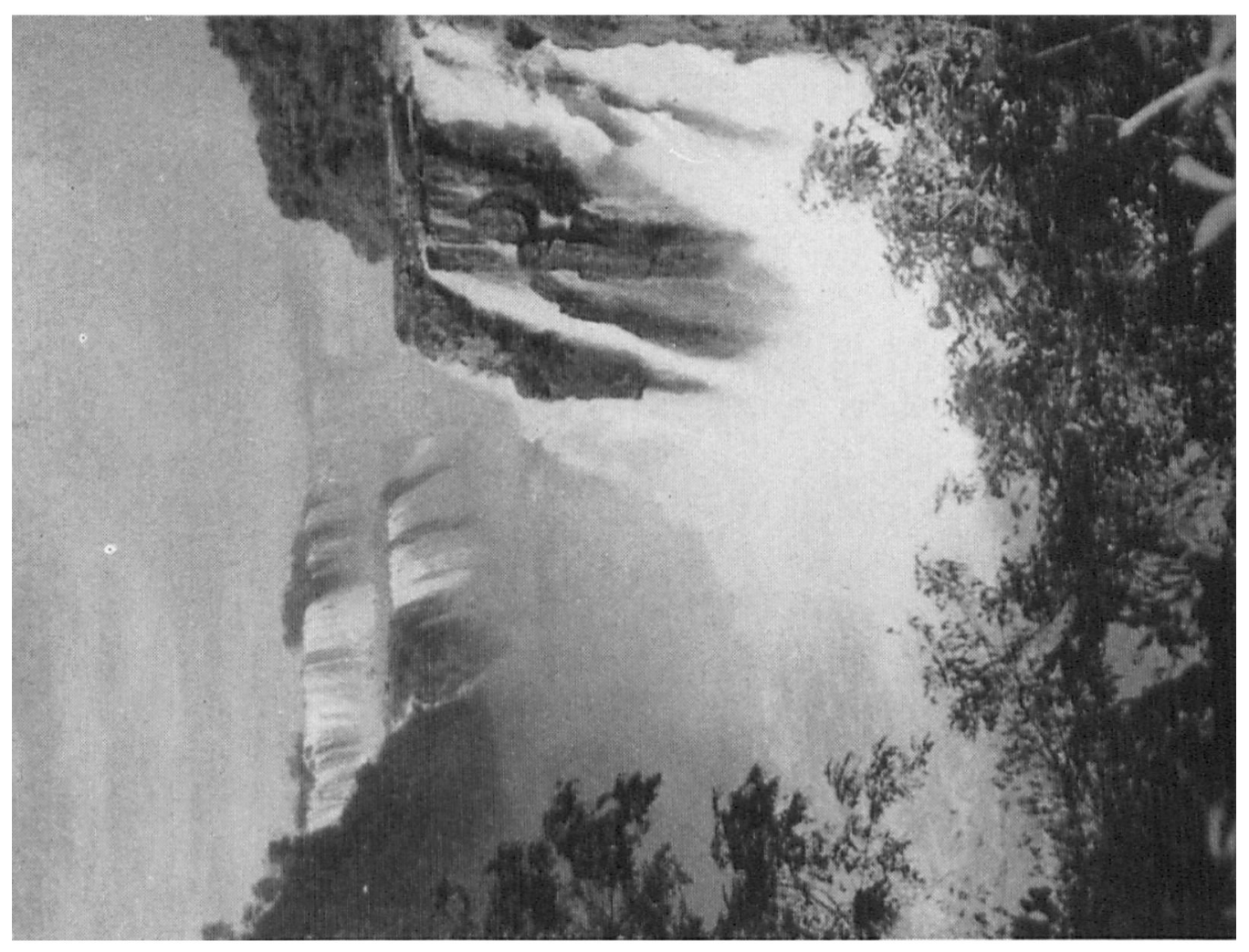

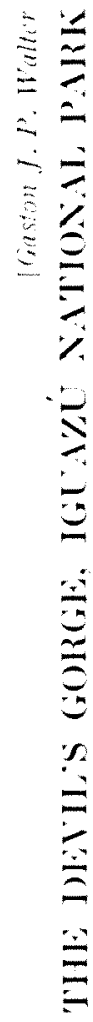

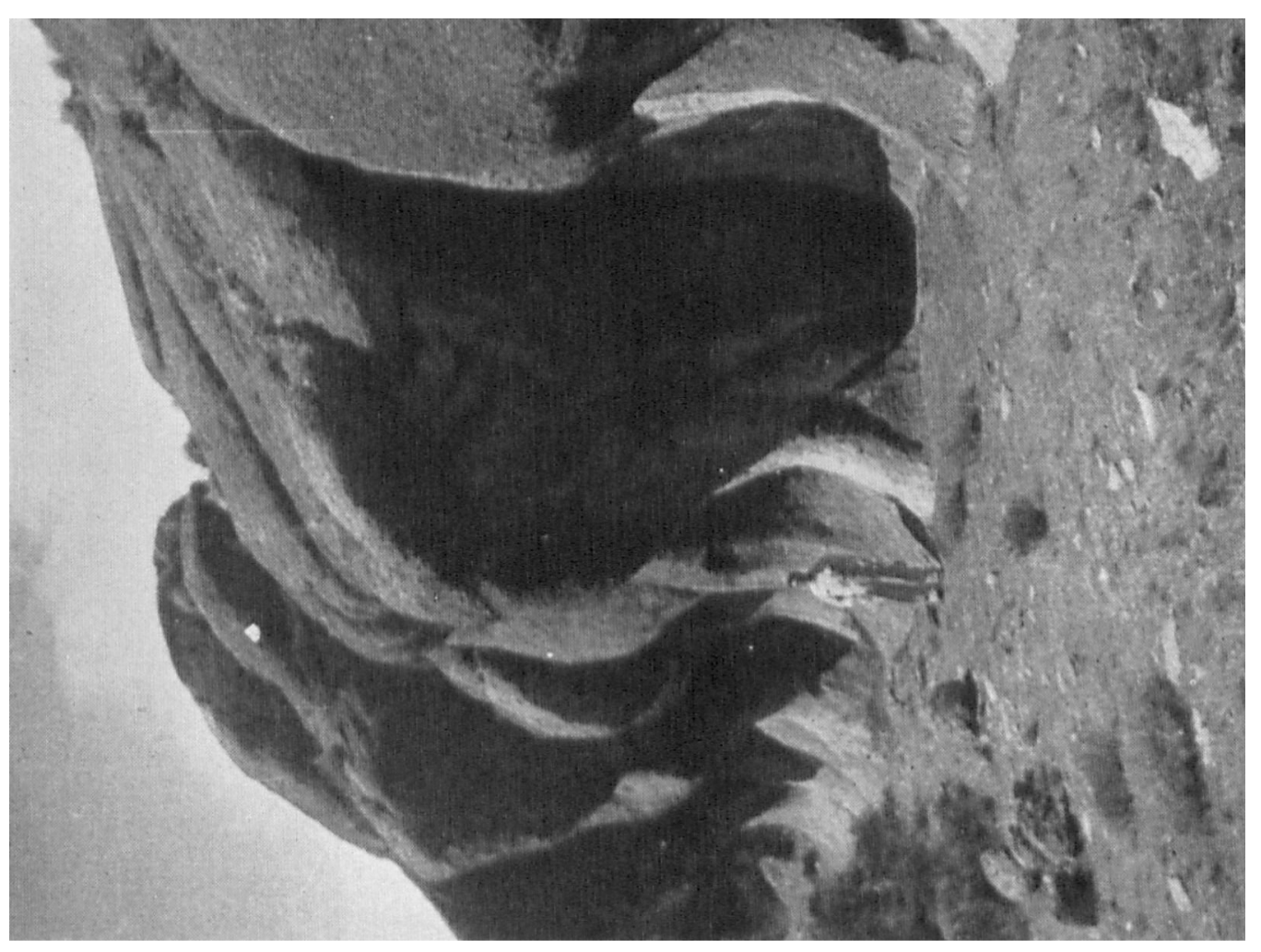

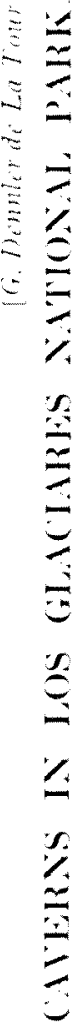


B. heterophylla, B. ilicifolia, and B. microphylla, the chaura, Pernettya macrocoronata, and the Magellan fuchsia, Fuchsia magellanica.

Perito Francisco P. Moneno National Park. Established in 1937 and named in honour of that great Argentine naturalist. 115,000 ha. (400 sq. miles).

Purpose.-A refuge for the guanaco and the rhea and to preserve the mountain scenery, with their snow-covered peaks and picturesque lakes.

Fauna.-The guanaco, the red fox, Pseudalopex.culpaeus culpaeus, the puma and the silky tuco-tuco are fairly common, and there are a few huemels. The grey fox, Pseudalopex gracilis patagonicus, has become exceedingly rare. The birds, include Darwin's rhea, the black-necked swan, Cygnus melanocoryphus, and the green-billed rail, Rallus rytirhynchos landbecki. In the high mountain region, a condor may occasionally be seen.

Flora.-In the mountains lenga woods predominate. On the tableland there are only shrubs, typically berberis.

Los Bosques Petrificados Nature Monument. Established 1954. 10,000 ha. (38 sq. miles).

Purpose.-The protection of the petrified forest of Araucarites mirabilis, estimated at seventy million years old.

Fauna.-Although this reserve is not specially designed for fauna protection, it contains many rare animals whose preservation should be assured. For example : the Patagonian ferret, Lyncodon patagonicus, the yellow-hipped pericote, Phyllotis xanthopygus, the greater yellow rat, Graomys griscoflavus, the clegant cligmodont, Eligmodontia elegans, and the mole-mouse, Chelemys vestitus alleni.

Laguna Brinca Nature Reserve. Established 1947. The White Lagoon and its surroundings, 11,250 ha. (40 sq. miles).

Purpose.-A refuge for the black-necked swan (by no means a scarce bird).

Fauna.-Important rodents, typical of the semi-desert, are the sand-mouse, Akodon arenicola, two mole mice, Chelemys vestitus fumosus, and Geoxus fossor, and the two tuco-tuco, Ctenomys mendocinus and $C$. emilianus. The birds include the common rhea, Rhea americana albescens, and the dark nightheron, Nycticorax n. obscurus.

Los Copanues National Park. Established 1937. Area 80,000 ha. (310 sq. miles). 
Administered by the Ministry of Technical Affairs.

Purpose.-Preservation of the hot, medicinal springs.

Fauna and Flora.-No study has been made. It would be useful to know what influence the hot springs, at an altitude of 1,800 metres, have on the vegetation. This reserve is the northern limit of the araucaria and the southern limit of the Andean cat, Oreailurus jacobita.

\section{THE NORTIERN RESERVES}

Iguazú National Park. Established 1934. 55,000 ha. (200 sq. miles).

Purpose.-Mainly to preserve the Iguazú cataracts-Iguazú means "great water" in the Guarani Indian language-but a strict nature reserve has been recommended in the sub-tropical forest of the Alto Iguazú river.

Fauna.-Mammals include the jaguar, Panthera onca palustris, the jaguarondi, Herpailurus yaguaroundi, the ocelot, Leopardus pardalis chibiguazu, the three deer, Ozotoceros bezoarticus leucogaster, Mazama simplicicornis and M. rufa, the two peccaries, Pecari tajacu and Tayassu pecari, the tapir, Tapirus t. terrestris, and the anteater, Tamandua tetradactyla. The grey Misiones squirrel, Guerlinguetus ingrami, the Misiones mouse, Thomasomys pictipes, and the nose-horned Misiones mouse, Oxymycterus misionalis, are specific regional animals for which this refuge is very welcome.

Among the birds are some typical of the Misiones formation, such as Tinamus solitarius, the wood peahen, Penelope superciliaris mayor, and the hawk-like caranchillo, Rupornis magnirostris magniplumis.

Flora.-Sub-tropical. The main species, protected because they are elsewhere exploited, are : the Yerba maté, Ilex paraguayensis, in its wild form ; the Misiones cedar, Cedrella fissilis ; the Brazil pine, Araucaria angustifolia; the urunday, Astronium balansae; the rose-wood, Aspidosperma polyneuron; both Lapacho trees, Tecoma ipe, the black one, and T. ochracea, the yellow one; the milk tree, Scbastiana brasiliensis, and the curupay, Piptadenia macrocarpa.

Doctor Angel Gallardo National Park. Proposed in 1935 at 15,000 ha. (60 sq. miles). Enlarged at the author's suggestion in 1943 to 60,000 ha. (240 sq. miles).

Purpose.-Preservation of the Chaco wild life and wilderness, 
especially to conserve a pure "quebrachal " that is a forest of quebracho or axe breaker Schinopsis balansae. The author has strongly recommended an extension to include more of this unique forest.

Fauna.-Mammals include jaguar, ocelot, Geoffroy's cat, Oncifelis geoffroyi; the small tiger-cat, Noctifelis pardinoides; the marsh deer, Blastocerus dichotomus; also the two Mazama deer, the tapir and peccaries (see Iguazú). The very rare maned wolf, or red wolf, Chrysocyon brachyurus ; the great anteater, Myrmecophaga tridactyla, the tamandua and the scarce, threebanded armadillo, Tolypeutes mataco, are also preserved in this park.

Birds.-The many birds include the white-throated falcon, Falco albigularis pax, and the red eagle, Heterospizias meridionalis rufulus.

Flora.-Besides the quebracho forest there are bottle trees, Chorisia insignis; caranday palms, Trithrinax campestris; several acacias and algarrobos, Prosopis spp.; and many others.

Finca Eu Rey National Park. Established 1948. 45,000 ha. (170 sq. miles).

Purpose.-Preservation of the flora of the Andean slopes. The author, in an earlier project, has pressed for an extension eastwards to form a reserve for the fauna of the adjacent western Chaco jungle.

Fauna.-Typical of the region are the salt-desert cat, Oncifelis salinarum; the crab-eating fox, Cerdocyon thous jucundus ; the vizacha de las cumbres, Lagidium tucumanum, and the weasel-headed armadillo, Euphractus sexcinctus. Among the rare animals are the tamandua anteater and the three-toed sloth, Bradypus tridactyla boliviensis.

Birds include the king vulture, Sarcorhamphus papa, and the rufous tinamou, Rhynchotus rufescens maculicollis, both becoming scarcer.

Flora.-There are three zones ; first the valley dry zone of shrubs and small trees; above that, forest with the cedar Cedrella balansae, a nut tree, Juglans australis, and others such as Enterolobium contortosiliquum in association with them.

The highest zone is alpine prairie where occasional thickets of Alnus jorullensis, Berberis laurina and some Baccharis show subsoil springs. 
Colonia Tacuarí Tourist Park and Hunting Reserve (Projected). Area 80,000 ha. (310 sq. miles).

Purpose.-Game reserve and tourism.

Fauna.-Many fur-bearing mammals find refuge here, as the area becomes inaccessible during the periodical floods of the Paranà river which borders the reserve. Animals include-Marsh deer, the two Mazama deer and the white bellied Pampa deer, Ozotoceros bezoarticus leucogaster; both peccaries, ocelot and Geoffroy's cat ; skunk, Conepatus suffocans ; capybara, Hydrochoerus hydrochaeris; the tapir and several armadillos.

The two alligators, Caiman latirostris, and C. sclerops, persecuted for their skins, could here find sanctuary. There are many ducks and other waterfowl.

Flora.-Palms are typical, particularly Arecastrum romanzoffianum, Copernicia australis and Trithrinax campestris. On the low hills are the algarrobos, Prosopis nigra and $P$. hassleri, also the ccibos, Erythrina crista-galli.

On the river banks are willows, especially the weeping willow, Salix humboldtiana.

Flonentino Amiegirino National Reserve. Established 1936. Area 300,000 ha. (1,150 sq. miles). Suggested by Dr. Hugo Salomon in 1927 ; boundaries altered in 1936 on the recommendation of the author. Consists of the Estero de Patiño swamp in the fork of the Pilcomayo river with an extension into the Formosa Chaco.

Purpose.-Prescrvation of the swamp and the aquatic and semi-aquatic fauna.

Fauna.-Tapir, swamp-decr, capybara, black-footed racoon, Procyon cancrivorus nigripes, the Chaco water rat, Scapteromys chacoensis, several armadillos, including, on the river banks, the very rare giant armadillo, Priodontes giganteus.

The reserve is rich in water birds, including the three storks, Jabiru mycteria, Euxenura maguari and Mycteria americana: the tiger heron, Tigrisoma lineatum marmoratum, "hoco" to the Indians, and the flamingo, Phoenicopterus ruber.

Flora.-The swamp vegetation of rush, reed, cane and sedge is varied by palms, e.g. Trithrinax campestris, and algarrobos.

Rio Pilcomayo National Park. Area 180,000 ha. (700 sq. miles). Proposed by the author as an international park to combine with the Paraguayan reserve on the River Confuso. Established and boundaries fixed in 1951. 
Purpose.-Conservation of the Chaco river forest and its wild life.

Fauna.-Mammals include all threc Argentine monkeys; the howler, Alouatta caraya, the capuchin, Cebus paraguayanus, and the very rare night-ape, or owl-faced monkey, Aotus azarae. The deer of Gallardo's reserve are commoner here. The armadillo, Burmeisteria retusa clorindae, a sub-species, limited to this region; the giant armadillo and the maned wolf are also found.

The birds are much the same as in Florentino Ameghino reserve and include the crowned harpy eagle, Harpyhaliaëtus coronatus.

Flora.-Typical of the river forest margins of the Chaco, marked by associations of aguaribay, Schinus molle; St. Anton's tree, Trevetia bicornuta; and the climbers Arrabidaea coleocalyj and $A$. mutabilis; joined to each other by the bushy liana, Pyrostegia venusta.

Sometimes the crown of a red or white quebracho overlooks the forest. The clearings are dominated by the black or yellow lapacho, Tecoma ipe or T. ochracea. On the river banks the white lapacho, Cybistax antisyphilitica is often found. 